\title{
An assessment of the distribution and conservation status of hornbill species in Thailand
}

\author{
Yongyut Trisurat, Vijak Chimchome, Anak Pattanavibool \\ Sitthichai Jinamoy, Siriporn Thongaree, Budsabong Kanchanasakha \\ Saksit Simcharoen, Kriangsak Sribuarod, Narong Mahannop \\ and PILAI POONSWAD
}

\begin{abstract}
Many hornbill species in Thailand are categorized as Endangered or Critically Endangered on the IUCN Red List. The objectives of this research were to predict hornbill distributions in Thailand and to assess the national conservation status of the species using extent of occurrence. We employed maximum entropy modelling, using 10 environmental variables that were believed to directly or indirectly influence hornbill distributions across Thailand, to predict the habitats potentially suitable for 10 of the country's 13 hornbill species. Data on the presence of hornbills were gathered from the Thailand Hornbill Project and additional field surveys in protected area complexes during 2004-2006. The results indicated that patch size is the most important factor affecting distribution, followed by latitude, ecoregion and distance to villages. All hornbill species were predicted to occur primarily in intact protected area complexes. The total extent of all hornbill habitats covers $9.3 \%$ of the country's land area. Seven of the 10 modelled species are at risk and the current distribution pattern is expected to reflect stochastic extinctions because of small population size. We recommend that the conservation status of Austen's brown hornbill Anorrhinus austeni and Tickell's brown hornbill Anorrhinus tickelli should be changed from Vulnerable to Endangered. The model identified five protected area complexes as hornbill hotspots in Thailand. These findings will help guide conservation management.
\end{abstract}

Keywords Anorrhinus, distribution, hornbill, Maxent, Thailand

YongYUT TRISURAT (Corresponding author) and VIJAK CHIMCHOME Faculty of Forestry and Center for Advanced Studies in Tropical Natural Resources, Kasetsart University, Bangkok 10900, Thailand. E-mail fforyyt@ku.ac.th

Anak Pattanavibool Wildlife Conservation Society, Thailand Program, Nontaburi, Thailand

Sitthichai Jinamoy and Pilai Poonswad Department of Microbiology, Mahidol University, Bangkok, Thailand

Siriporn Thongaree, Budsabong Kanchanasakha, Saksit Simcharoen, KriangSaK SRibuarod and Narong Mahannop Department of National Park, Wildlife and Plant Conservation, Bangkok, Thailand

Received 27 December 2010. Revision requested 12 May 2011.

Accepted 1 June 2011. First published online 9 May 2013.

\section{Introduction}

The Asian hornbills, family Bucerotidae, comprise 54 1 species (Kemp, 2001). They are primarily frugivorous, eating a variety of fruits, with figs predominant in their diet, but they also consume a diversity of animal prey (Poonswad, 1998). They play an important role in seed dispersal in tropical forests and have been referred to as the 'farmers of the forest' (Kinnaird \& O'Brien, 2007). The decline of hornbills has affected the dispersal and recruitment of large-seeded tree species in logged forests in the foothills of the Indian Eastern Himalayas (Sethi \& Howe, 2009) and monsoon evergreen forest in Khao Yai, Thailand (Kitamura et al., 2004). Hornbills are useful indicators of forest condition and human disturbance because they require large tracts of forest with large fruiting trees for feeding and nesting (Poonswad et al., 2005; Kinnaird \& O'Brien, 2007).

The accelerated loss and fragmentation of Asian forest in the 1990s, followed by hunting, are the most commonly cited reasons for hornbills being threatened (Poonswad et al., 2005; Kinnaird \& O'Brien, 2007). Thailand has lost as much as $70 \%$ of its original forest cover (DNP, 2007). Landscape patterns are significant factors influencing the distribution of hornbills (O'Brien et al., 1998; Raman \& Mudappa, 2003; Pattanavibool et al., 2004; Sitompul et al., 2004; Kinnaird \& O'Brien, 2007). Isolation of suitable food patches prevents food tracking behaviour, and adversely affects populations of avian frugivores through starvation, and food plants through interruption of seed dispersal (Lehouck et al., 2009). Sitompul et al. (2004) indicated that hornbills are more vulnerable to stochastic effects and patch size than overall resource availability. O'Brien et al. (1998) found that the Sumba hornbill Aceros everetti was rare or absent in forest patches $<10 \mathrm{~km}^{2}$.

Thailand is home to 13 species and one subspecies of hornbill and Thai researchers have conducted long-term studies of hornbills (Poonswad, 1998; THP, 2009). All species except the oriental pied hornbill Anthracoceros albirostris are categorized nationally as threatened species (ONEP, 2007) but none are endemic to Thailand (Kinnaird \& O'Brien, 2007). Estimation of changes in the distribution of hornbills in Thailand (Poonswad, 1998) suggests that c. $32 \%$ of the land area contains potentially suitable habitats for hornbills but this is less than that of earlier assessments by Lekagul \& Cronin (1974). 
There are a number of modelling methods available for predicting the potential distribution of species. These models are based on the assumption that the relationship between a given pattern of interest (e.g. species abundance or presence/absence) and a set of factors assumed to control it can be quantified (Phillips et al., 2006; Trisurat \& Toxopeus, 2011). Recent advances employing geographical information systems (GIS) allow correlative modelling of species' distributions for large geographical areas, which is useful when detailed information about the natural history of species is lacking (Anderson et al., 2002; Trisurat \& Toxopeus, 2011). The objectives of our research were to predict hornbill distributions in Thailand and assess their current conservation status based on extent of occurrence derived from GIS-based habitat modelling.

\section{Methods}

\section{Study area}

We assessed hornbill distributions at two levels: the entire 513,200 $\mathrm{km}^{2}$ of Thailand, and the 12 protected area complexes comprising a total of $65,528 \mathrm{~km}^{2}$ that potentially contain hornbill habitat. Six additional complexes in Thailand have no records of hornbills in the last 2 decades (Poonswad, 1998) and the remaining forest cover in these complexes is small and severely fragmented.

\section{Data collection}

We collected data on four abiotic factors (altitude, slope, latitude and annual rainfall), four biotic factors (ecoregion type, vegetation type, patch size and distance to forest patch $>50 \mathrm{~km}^{2}$, which included evergreen, deciduous or mixed forest, disturbed forest and forest plantation) and two anthropogenic factors (distance to village and distance to road) that have been identified as directly or indirectly affecting patterns of abundance and distribution of hornbills (O'Brien et al., 1998; Poonswad, 1998; Sitompul et al., 2004; Kinnaird \& O'Brien, 2007). Vegetation types were derived from a 2006 1:50,000 forest type map (DNP, 2007). Patch size and distance to large forest patch were derived from a vegetation map, and ecoregion was extracted from the WWF ecoregions map (Olson et al., 2001). Altitude and slope were extracted and interpolated from the $20-\mathrm{m}$ contour lines of 1:50,000 topographic maps. Distance to road was digitized from topographic maps. Average annual rainfall was interpolated from mean 30 -year rainfall data recorded at weather stations across the country, using universal kriging (Theobald, 2005). All environmental variables were converted to raster format to perform spatial analyses with a GIS. A pixel resolution of $400 \mathrm{~m}$ was chosen because this is intermediate in size between the fine resolution of the topographic maps and the coarse resolution of the climatic variables, and corresponds to the minimum mapping unit of the vegetation type map.

We constructed a matrix of correlations between all possible pairs of variables. Pearson's correlations indicated that all pairs had coefficients $<0.70$. Thus, there do not appear to be problems with multicollinearity (Graham et al., 2008), which can otherwise result in model overfitting (Peterson et al., 2007), and therefore all 10 variables were used for modelling species distributions.

\section{Species distribution modelling}

The processes for mapping distributions comprised: (1) collection of observation points, (2) generation of distributions, (3) assessment of status, and (4) determination of priority areas for hornbill conservation. We collected species presence points from the Thailand Hornbill Project and additional field surveys during 2004-2006. Since the 1980 s the Project has regularly collected data on sightings and vocal detections of hornbills (THP, 2009) but geographical locations have only been recorded since 2000. The 2004-2006 data were jointly collected by the Project and the Wildlife Conservation Society Thailand. Survey teams comprising 3-4 people walked along wildlife trails or patrol routes, recording hornbill locations using a global positioning system and topographic maps.

Although we initially aimed to model the distributions of all 13 hornbill species in Thailand, we only had adequate records $(>20)$ for modelling for 10 of the species (Table 1 ). From the available species modelling techniques we selected maximum entropy modelling (Phillips et al., 2006) because it was specifically developed to model species distributions with presence-only data (Phillips et al., 2006), outperforms most other modelling techniques (Tognelli et al., 2009), is least affected by geo-referencing errors (Graham et al., 2008), and performs best when few presence records are available (Wisz et al., 2008).

The occurrence data for each species was randomly divided into two datasets. Seventy-five percent (training data) were used to generate distribution models and $25 \%$ (test data) were kept as independent data to test the accuracy of the distribution model using the area under curve (AUC) of a receiver operating characteristic (Hosmer \& Lemeshow, 2000).

We transformed the continuous probability of occurrence of each model output (0.00-1.00) into a binary prediction by applying the sensitivity-specificity sum maximization threshold, which is a promising approach for predicting species distributions (Liu et al., 2005). If the probability value was equal or greater than this threshold value it was classified as presence, and otherwise as absence. In addition, we used the contingency matrix to evaluate the 
TABLE 1 The 10 hornbill species in Thailand whose distributions could be modelled, with the number of records of each, the percentage contributions of the 10 environmental variables to the spatial distribution model for each species, and the accuracies of the distribution models (AUC) for training and test data (see text for further details). The three species for which there were $<10$ records (black hornbill Anthracoceros malayanus, 4 records; wrinkled hornbill Rhyticeros corrugatus, 4; and plain-pouched Rhyticeros subruficollis, 8) were not modelled.

\begin{tabular}{|c|c|c|c|c|c|c|c|c|c|c|c|c|c|}
\hline \multirow[b]{2}{*}{ Species } & \multirow[b]{2}{*}{$\begin{array}{l}\text { No. of } \\
\text { records }\end{array}$} & \multicolumn{10}{|c|}{ Environmental variables (\% contribution) } & \multicolumn{2}{|l|}{ AUC } \\
\hline & & Rain & Patch size & Latitude & Ecoregion & $\begin{array}{l}\text { Distance } \\
\text { to village }\end{array}$ & $\begin{array}{l}\text { Distance } \\
\text { to main } \\
\text { road }\end{array}$ & Forest & DEM & $\%$ slope & $\begin{array}{l}\text { Distance } \\
\text { to large } \\
\text { patch }\end{array}$ & Training & Test \\
\hline $\begin{array}{l}\text { Rufous-necked hornbill } \\
\text { Aceros nipalensis }\end{array}$ & 27 & 0.9 & 54.0 & 0.1 & 40.6 & 1 & 0.1 & 0.1 & 3 & 0.3 & 0.2 & 1.00 & 1.00 \\
\hline $\begin{array}{l}\text { Tickell's brown hornbill } \\
\text { Anorrhinus tickelli }\end{array}$ & 67 & 0.6 & 49.4 & 2.2 & 36.0 & 0.7 & 5.6 & 1.8 & 2.2 & 1 & 0.5 & 0.97 & 0.98 \\
\hline $\begin{array}{l}\text { Austen's brown hornbill } \\
\text { Anorrhinus austeni }\end{array}$ & 44 & 20.8 & 6.4 & 1.2 & 32.7 & 0.7 & 3.1 & 35 & 0.1 & 0.1 & 0.1 & 0.99 & 0.99 \\
\hline $\begin{array}{l}\text { Rhinoceros hornbill } \\
\text { Buceros rhinoceros }\end{array}$ & 123 & 3.2 & 14.3 & 34.8 & 38.4 & 4.7 & 0.2 & 2.8 & 1.6 & 0.1 & 0.1 & 1.00 & 1.00 \\
\hline $\begin{array}{l}\text { Helmeted hornbill } \\
\text { Rhinoplax vigil }\end{array}$ & 164 & 27.3 & 36.1 & 18.9 & 3.4 & 2.6 & 0.2 & 9.5 & 1.7 & 0.1 & 0.2 & 1.00 & 1.00 \\
\hline $\begin{array}{l}\text { Bushy-crested hornbill } \\
\text { Anorrhinus galeritus }\end{array}$ & 139 & 35.2 & 32.6 & 15.4 & 4.2 & 4.1 & 2.4 & 2.2 & 1.8 & 1.2 & 0.9 & 1.00 & 0.99 \\
\hline $\begin{array}{l}\text { White-crowned hornbill } \\
\text { Berenicornis comatus }\end{array}$ & 46 & 3.4 & 62.8 & 8.6 & 17.7 & 0.1 & 3.4 & 0.9 & 0.7 & 1.2 & 1.2 & 0.99 & 0.99 \\
\hline $\begin{array}{l}\text { Oriental pied hornbill } \\
\text { Anthracoceros } \\
\text { albirostris }\end{array}$ & 270 & 3.9 & 14.4 & 11.3 & 6.7 & 32.1 & 2.1 & 6.7 & 1.2 & 1.4 & 20.2 & 0.98 & 0.96 \\
\hline $\begin{array}{l}\text { Wreathed hornbill } \\
\text { Rhyticeros undulatus }\end{array}$ & 184 & 2.7 & 42.2 & 14.1 & 3.1 & 19.5 & 3.7 & 3.3 & 1.7 & 0.2 & 9.5 & 0.99 & 0.98 \\
\hline $\begin{array}{l}\text { Great hornbill } \\
\text { Buceros bicornis }\end{array}$ & 457 & 5 & 29.4 & 18.5 & 4.4 & 16.2 & 8.1 & 5.2 & 3.7 & 1.8 & 7.7 & 0.99 & 0.98 \\
\hline Mean (range) & & $\begin{array}{l}10.3 \\
(0.6-35.2)\end{array}$ & $\begin{array}{l}34.2 \\
(6.4-62.8)\end{array}$ & $\begin{array}{l}12.5 \\
(0.1-34.8)\end{array}$ & $\begin{array}{l}18.7 \\
(3.1-40.6)\end{array}$ & $\begin{array}{l}8.2 \\
(0.1-32.1)\end{array}$ & $\begin{array}{l}2.9 \\
(0.1-8.1)\end{array}$ & $\begin{array}{l}6.8 \\
(0.1-35.0)\end{array}$ & $\begin{array}{l}1.8 \\
(0.1-3.7)\end{array}$ & $\begin{array}{l}0.7 \\
(0.1-1.8)\end{array}$ & $\begin{array}{l}4.1 \\
(0.1-20.2)\end{array}$ & $\begin{array}{l}0.99 \\
(0.97-1.00)\end{array}$ & $\begin{array}{l}0.99 \\
(0.96-1.00)\end{array}$ \\
\hline
\end{tabular}


TABLE 2 The three criteria used to determine areas of conservation priority for hornbills (Table 1) in Thailand's protected area complexes, with the scores used for assessing priority areas for conservation (see text for further details).

\begin{tabular}{ll}
\hline Category (by criterion) & Score \\
\hline Species richness & 3 \\
$\geqslant 6$ species & 2 \\
$4-5$ species & 1 \\
$\leqslant 3$ species & \\
Potentially suitable area & 3 \\
$\geqslant 3,000 \mathrm{~km}^{2}$ & 2 \\
$1,000-2,000 \mathrm{~km}^{2}$ & 1 \\
$\leqslant 1,000 \mathrm{~km}^{2}$ & \\
No. of Endangered/Critically Endangered species & 3 \\
$\geqslant 3$ species & 2 \\
2 species & 1 \\
$\leqslant 1$ species & \\
\hline
\end{tabular}

classification errors of omission and commission of predicted distributions derived from the models.

The IUCN Red List criteria (2001) uses five quantitative criteria (A-E) to evaluate the status of threatened species. We used geographical range in the form of extent of occurrence (criterion $\mathrm{B}_{1}$ ) and the sub-criterion for severely fragmented to determine the conservation status of hornbills. We used the potentially suitable habitat derived from Maxent modelling to represent the estimated extent of occurrence.

Priority areas for conservation of hornbills were determined using three criteria: (1) species richness, (2) number of Endangered or Critically Endangered species, and (3) total area of potentially suitable habitat (Table 2). The latter was evaluated by overlaying the predicted potentially suitable habitats for the 10 hornbill species for which there were sufficient data for modelling. Each of the three criteria was scored in the range $1-3$, where 3 represents the most favourable condition for high conservation priority, 2 an intermediate condition and 1 the least favourable. These scores were summed, giving a score in the range 3-9. Protected area complexes with score ranges of $7-9,5-6$ and $\leqslant 4$ were considered as areas of high, moderate and low conservation priorities, respectively.

\section{Results}

Species records and model performance

A total of 1,537 records were gathered from the Thailand Hornbill Project and additional field surveys. There were $<10$ records of the black hornbill Anthracoceros malayanus, wrinkled hornbill Rhyticeros corrugatus and plain-pouched hornbill Rhyticeros subruficollis. The lowest number of records for the 10 evaluated species was 27 , for the rufous-necked hornbill Anthracoceros nipalensis, and the greatest number was 457 records, for the great hornbill Buceros bicornis (Table 1).

Of the 10 environmental factors patch size made the highest percentage contribution to the spatial distribution model, followed by ecoregion type, latitude and annual rainfall (Table 1). The lowest contribution was from slope. The contribution of each factor varied between species. For example, the contribution of ecoregion was high for Austen's brown hornbill Anorrhinus austeni and Tickell's brown hornbill Anorrhinus tickelli but relatively low for bushy-crested hornbill Anorrhinus galeritus, oriental pied hornbill, wreathed hornbill Rhyticeros undulatus and great hornbill because these species are widely distributed in Thailand. The accuracies of the distribution models for both training and test data were high (AUC $>0.9$ ) for all species (Table 1).

We compared the predicted distributions and actual occurrences obtained from recent surveys (Fig. 1). Overall prediction accuracy for the 10 modelled species was $93.3 \%$. However, we found a few records of Tickell's brown hornbill in Mae Ping-Omkoi and Chumporn complexes, of helmeted hornbill in Khao Luang, and of wreathed and great hornbills in Doi Phukha complex, where they were predicted to be absent. Bushy-crested hornbill and white-crowned hornbill Berenicornis comatus were not sighted in Chumporn complex although they were predicted to be present.

\section{Distributions}

The predicted distributions and extents of occurrence of the 10 modelled hornbill species are shown in Fig. 1 and Table 3 , respectively. The predicted area of potentially suitable habitat for rufous-necked hornbill is the smallest of the studied species. Our field surveys during 2004-2006 showed that the last population inhabits fragmented remnants of the Western Forest complex (Fig. 1).

The largest patch of potentially suitable habitat for Tickell's brown hornbill is predicted to be in the Western Forest complex and a small patch is predicted in the Kraeng Krachan complex. It was relatively rare in Chumporn complex over the last 3 decades (Poonswad et al., 1998) and our field surveys during 2004-2006 indicated that it has now disappeared there; the distribution model also predicted its absence. The predicted potentially suitable habitats for Austen's brown hornbill (Table 3) are the large patches in the Dong Phayayen-Khao Yai and Phu Khiew-Nam Nao complexes in the north-east (Fig. 1, Table 4).

Like the rufous-necked hornbill, the rhinoceros hornbill is restricted to extensive tracts of primary tropical rainforest, in Hala Bala complex (Fig. 1), and its distribution is more limited than other hornbill species (Table 3). The distributions of the helmeted hornbill Rhinoplax vigil, 

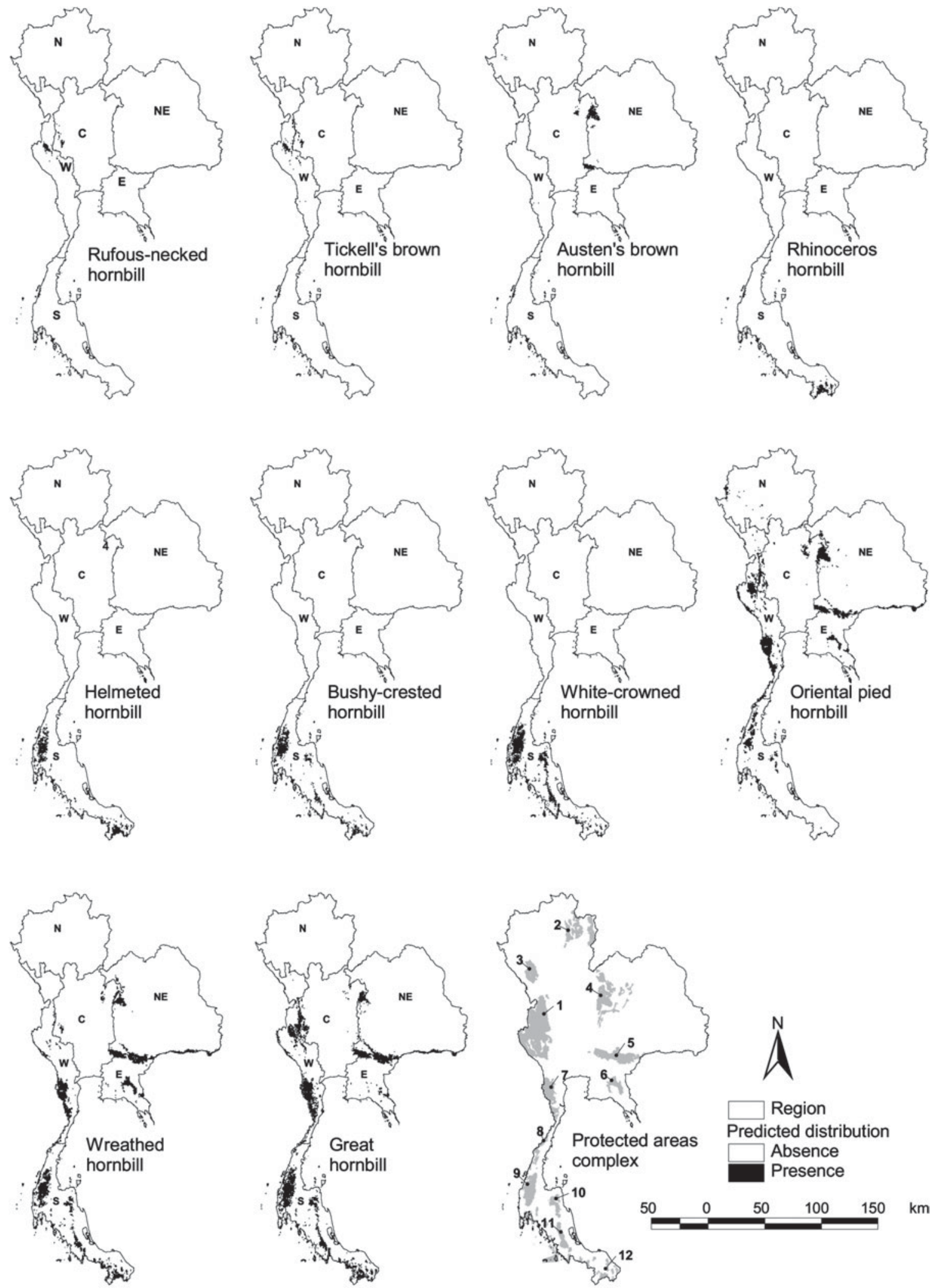

FIG. 1 Predicted distribution of the 10 (of 13) hornbill species in Thailand for which there are sufficient records for modelling (Table 1), with sightings made during 2004-2006, and the 12 protected area complexes (see also Table 4) that potentially contain hornbill habitat: 1, Western Forest complex; 2, Doi Phuka-Mae Yom; 3, Mae Ping-Omkoi; 4, Phu Khiew-Nam Nao; 5, Dong Phayayen-Khao Yai; 6, Eastern Forest complex; 7, Khaeng Krachan; 8, Chumporn; 9, Klong Saeng-Khao Sok; 10, Khao Luang; 11, PP-Andaman-Khao Banthad; 12, Hala Bala. 
TABLE 3 Predicted extents of occurrence for each of the 13 hornbill species nationally in Thailand and in the country's protected areas, the area of potentially suitable habitat in 1992, and the global and national Red List status, and our recommended national Red List status based on our findings in this study. The plain-pouched, wrinkled and black hornbills were not modelled because of the paucity of records (Table 1).

\begin{tabular}{|c|c|c|c|c|c|c|}
\hline \multirow[b]{2}{*}{ Hornbill species } & \multirow{2}{*}{$\begin{array}{l}\text { National, } \\
\mathrm{km}^{2}(\%)\end{array}$} & \multirow{2}{*}{$\begin{array}{l}\text { Protected areas, } \\
\mathrm{km}^{2}(\%)\end{array}$} & \multirow{2}{*}{$\begin{array}{l}\text { Suitable habitat } \\
\text { in } 1992^{1}\left(\mathrm{~km}^{2}\right)\end{array}$} & \multicolumn{3}{|c|}{ Red List status ${ }^{2}$} \\
\hline & & & & Global $^{3}$ & National $^{4}$ & This study $^{5}$ \\
\hline Rufous-necked & $1,315(0.26)$ & $1,288(97.95)$ & 19,536 & VU & EN & EN \\
\hline Tickell's brown & $1,864(0.36)$ & $1,770(94.95)$ & $58,851^{6}$ & NT & VU & $\mathrm{EN}$ \\
\hline Austen's brown & $3,169(0.62)$ & $2,557(80.68)$ & $58,851^{6}$ & NT & VU & $\mathrm{EN}$ \\
\hline Rhinoceros & $1,886(0.37)$ & $1,613(85.52)$ & 6,083 & NT & EN & $\mathrm{EN}$ \\
\hline Helmeted & $6,812(1.33)$ & $3,973(58.32)$ & 12,777 & NT & $\mathrm{EN}$ & $\mathrm{EN}^{7}$ \\
\hline Bushy-crested & $7,723(1.51)$ & $5,641(73.04)$ & 10,555 & $\mathrm{LC}$ & $\mathrm{VU}$ & VU \\
\hline White-crowned & $12,041(2.35)$ & $7,722(64.13)$ & 9,914 & NT & VU & VU \\
\hline Oriental pied & $25,507(4.97)$ & $23,180(90.70)$ & 90,864 & $\mathrm{LC}$ & $\mathrm{LC}$ & $\mathrm{LC}^{8}$ \\
\hline Wreathed & $27,759(5.41)$ & $11,803(42.52)$ & 74,640 & $\mathrm{LC}$ & $\mathrm{VU}$ & NT \\
\hline Great & $36,131(7.05)$ & $13,053(36.13)$ & 107,951 & NT & $\mathrm{VU}$ & NT \\
\hline Plain-pouched & & & 5,524 & VU & EN & \\
\hline Wrinkled & & & 2,067 & NT & $\mathrm{CR}$ & \\
\hline Black & & & 2,106 & NT & $\mathrm{CR}$ & \\
\hline Total $^{9}$ & 47,646 & 37,554 & 107,951 & & & \\
\hline
\end{tabular}

${ }^{1}$ Poonswad (1998)

${ }^{2}$ LC, Least Concern; NT, Near Threatened; VU, Vulnerable; EN, Endangered; CR, Critically Endangered

${ }^{3}$ BirdLife International (2009)

${ }^{4}$ ONEP (2007)

${ }^{5}$ National status derived from this study

${ }^{6}$ Habitats of Tickell's brown and Austen's brown hornbills were combined

${ }^{7}$ Initially categorized as VU (see Discussion for further details)

${ }^{8}$ Initially categorized as NT (see Discussion for further details)

${ }^{9}$ More than one hornbill species inhabits individual areas

bushy-crested hornbill and white-crowned hornbill are similar (Fig. 1). Large areas of suitable habitat for these species occur in Khlong Saeng-Khao Sok, PP-AndamanKhao Banthad and Hala Bala complexes (Table 4).

The oriental pied, wreathed and great hornbills were predicted to be present in many protected area complexes (Fig. 1). They are unlikely to exist in northern Thailand, however, although a few observations of the first two species were recorded in Doi-Phuka-Mae Yom and Mae Ping-Mae Yom complexes during 2004-2006.

\section{Hornbill concentrations and hotspots}

Overlaying the predicted potentially suitable habitats of the 10 hornbill species indicates that the total extent of suitable habitat for these species is $47,646 \mathrm{~km}^{2}$ ( $9.28 \%$ of Thailand's land area; Table 3, Fig. 2). Of this $37,554 \mathrm{~km}^{2}(78 \%)$ is in 12 protected area complexes (Table 3 ) and $10,092 \mathrm{~km}^{2}(22 \%)$ is in buffer zones or remnant forests. The largest hornbill habitat is in the Western Forest complex (Table 4). Approximately $75 \%$ or more of Dong Phayayen-Khao Yai, Kaeng Krachan, Eastern Forest, Khlong Saeng-Khao Sok, Khao Luang and Hala Bala complexes are predicted to be potentially suitable for hornbills. Doi Phuka-Mae Yom and Mae Ping-Omkoi complexes in the north are predicted to be unsuitable for the modelled species (Table 4).
We consider the Western Forest, Khlong Saeng-Khao Sok, Khao Luang and Hala Bala complexes to be hornbill hotspots because they have sum values of scores for species richness, Endangered or Critically Endangered species, and total area of potentially suitable habitat $\geqslant_{7}$ (Table 4). Although Dong Phayayen-Khao Yai complex only had a sum value of 6 we also regard this complex as a hornbill hotspot because of the presence of Austen's brown hornbill. The second priorities for hornbill conservation (sum values of 5-6) were Phu Khiew-Nam Nao, Khaeng Krachan, Chumporn and PP-Andaman-Khao Banthad complexes.

The Western Forest complex includes five hornbill species, two of which are Endangered (rufous-necked and Tickell's brown hornbills). Approximately $96 \%$ of Khlong Saeng-Khao Sok complex is predicted to be potentially suitable hornbill habitat, the highest of the 12 protected area complexes. Helmeted hornbill (Endangered) and wrinkled hornbill (Critically Endangered) were also sighted in this area. Although potentially suitable hornbill habitats in Hala Bala are $<2$,000 $\mathrm{km}^{2}$ it has the highest number of studied species (Table 4). In addition, Hala Bala contains the only habitat in Thailand for the rhinoceros and wrinkled hornbills (THP, 2009), and Khao Luang is the only area in which our survey team sighted the black hornbill. 


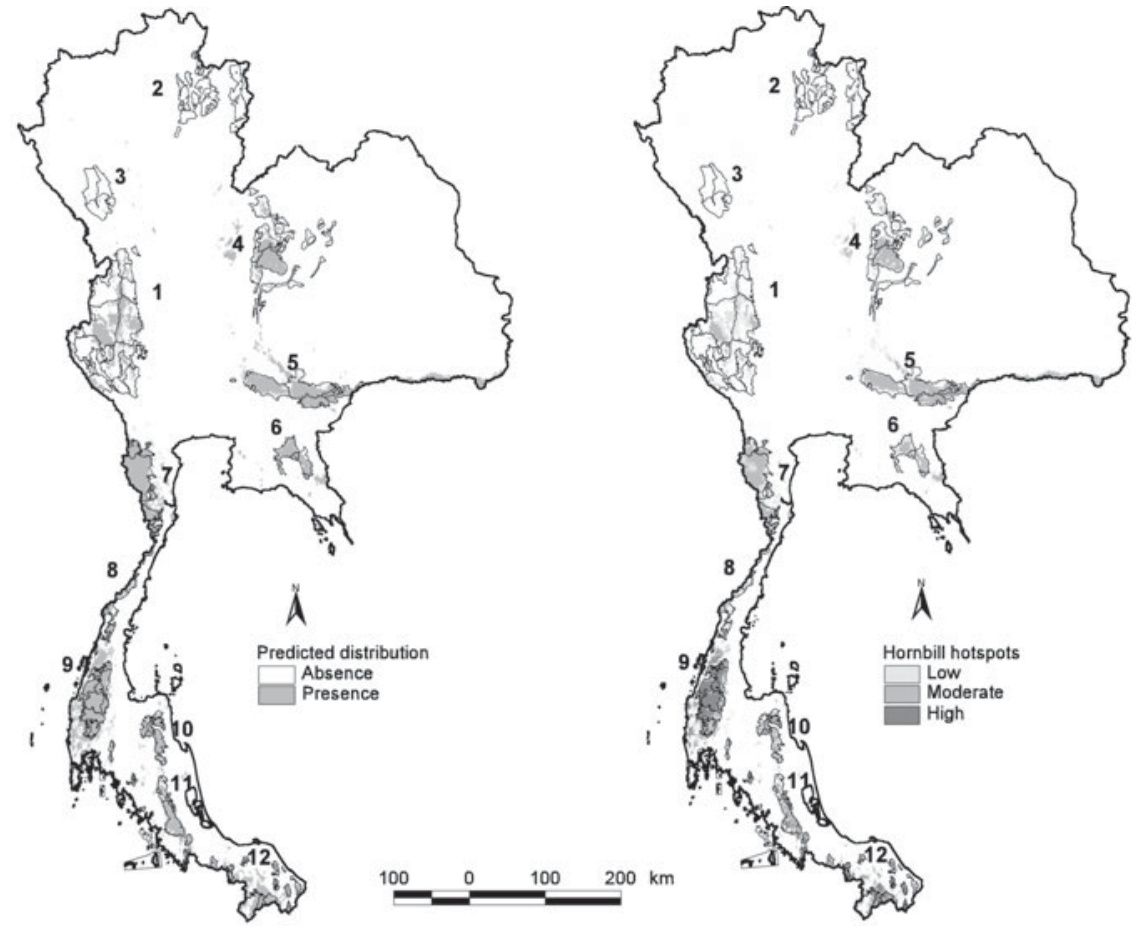

FIG. 2 The predicted distribution of hornbills (a), and hotspots of hornbill diversity (b) in Thailand (see text for details). The numbers indicate the 12 protected area complexes: 1, Western Forest complex; 2, Doi Phuka-Mae Yom; 3, Mae Ping-Omkoi; 4, Phu Khiew-Nam Nao; 5, Dong Phayayen-Khao Yai; 6, Eastern Forest complex; 7, Khaeng Krachan; 8, Chumporn; 9, Klong Saeng-Khao Sok; 10, Khao Luang; 11, PP-Andaman-Khao Banthad; 12, Hala Bala.

\section{Discussion}

\section{Hornbill distribution models}

This research provides the first spatially explicit assessment of hornbills at the national and protected area complex levels in Thailand other than an earlier study at a national level (Poonswad, 1998). Kinnaird \& O’Brien (2007) studied the hornbills at a regional level, for South-east Asia.

Our results indicate that the extents of potentially suitable habitats for hornbills, regardless of confirmed sightings, are significantly less than the areas of suitable habitat in 1992 (Poonswad, 1998). For example, the area of potentially suitable habitat for the rufous-necked hornbill has decreased from $19,536 \mathrm{~km}^{2}$ in 1992 to $1,288 \mathrm{~km}^{2}$ in 2006 (Table 3). This could be a result of deforestation since 1992 (DNP, 2007) and possible bias in the methods used by Poonswad (1998), which were derived by overlaying preferred forest habitat and the altitude range of each hornbill species. This method usually overestimates habitat area (Trisurat \& Toxopeus, 2011).

\section{Current hornbill distributions}

The predicted distributions of hornbill species are currently concentrated in intact protected area complexes. The contribution of protected areas to predicted hornbill habitat has increased from 32\% in 1992 (Poonswad, 1998) to c. 78\% of total hornbill habitats. This indicates the important role of protected areas in conserving hornbill species. Hornbills are unlikely to survive in northern Thailand (Fig. 1).
The rufous-necked hornbill sighted in Mae-Ping-Omkoi and Doi Phukha-Mae Yom complexes by Lekagul \& Cronin (1974) disappeared because of hunting by hill tribes both within and outside protected areas, forest encroachment for cash crops and poor law enforcement (THP, 2009). The brown and great hornbills have declined in Mae Ping-Omkoi and become locally extirpated at this protected area complex as a result of deforestation and poaching (Pattanavibool et al., 2004).

Nevertheless, potentially suitable habitats for some hornbill species (e.g. wreathed, great and white-crowned) are predicted to occur outside protected areas (Fig. 1). This is because of the ability of these species to inhabit a wide range of forest habitats, including forest on islands, and because they sometimes range into areas of open deciduous forest (Poonswad, 1998; Kemp, 2001; Kinnaird \& O’Brien, 2007), unlike rufous-necked, rhinoceros, Austen's brown and Tickell's brown hornbills. The rufous-necked hornbill is restricted to remaining montane forest (Kemp, 2001), and Austen's brown and Tickell's brown hornbills occur in eastern and western Thailand, respectively (Poonswad, 1998; THP, 2009).

\section{Hornbill hotspots}

Based on species richness, conservation status and potentially suitable habitat size criteria, we consider five protected area complexes (Western Forest complex, Dong PhayayenKhao Yai, Khlong Saeng-Khao Sok, Khao Luang and Hala Bala), which support the richest hornbill assemblages and the most threatened species (rufous-necked, Austen's 


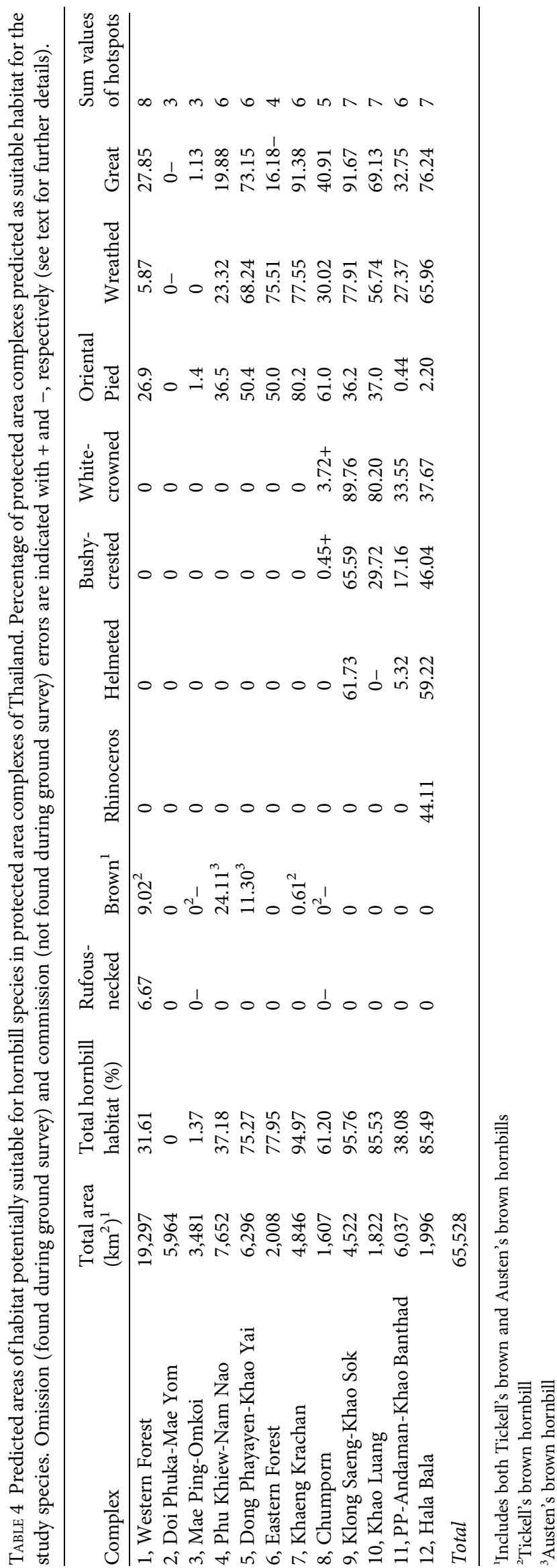

brown, Tickell's brown, rhinoceros and helmeted hornbills), to be hornbill hotspots in Thailand. These areas are therefore high priorities for conservation. These five complexes cover $6.61 \%$ of the country's land area and comprise c. $57 \%$ of the total hornbill habitat (Table 4). We include the Dong Phayayen-Khao Yai forest complex even though its sum value was 6 because of its importance for Austen's brown hornbill. In addition, this complex is a Natural World Heritage Site and is isolated from other complexes. Thus it plays a role as a source of hornbills in the north-east. The Hornbill Project Thailand has conducted research in Khao Yai National Park since 1981 (THP, 2009) and therefore this site provides valuable information on temporal trends in hornbill abundance.

\section{Conservation status and conservation efforts}

Compared to our modelling approach, previous conservation assessments of the hornbills of Thailand have largely depended on expert knowledge (ONEP, 2007) or have used a simple definition of potentially suitable habitats (Poonswad, 1998). Based on our reassessment we recommend that the Thailand Red List authority changes the status of Tickell's and Austen's brown hornbills from Vulnerable (ONEP, 2007) to Endangered. The predicted extent of occurrence for both species is $<5,000 \mathrm{~km}^{2}$ and they occur at $<5$ locations (Table 3 ). Considering the criterion B1 (IUCN, 2001) and its predicted distribution suggests that the national status of the Helmeted hornbill should be changed from Endangered to Vulnerable. However, as c. $42 \%$ of its habitat was predicted to be outside protected areas, where protection is poor, its status should probably remain unchanged. We recommend that conservation efforts should be strengthened to conserve rufousnecked, rhinoceros, Tickell's brown and Austen's brown hornbills because they are most at risk, and the current small populations are susceptible to the effects of stochastic factors (Lande, 1993; Fraterrigo et al., 2009; Reed, 2010).

The national status of the wreathed and great hornbills should potentially be changed from Vulnerable (ONEP, 2007) to Near Threatened because their potentially suitable habitats or predicted extent of occurrence are $>20,000 \mathrm{~km}^{2}$ and they persist in $>10$ locations. Our modelling suggests that the status of the oriental pied hornbill should be changed from Least Concern to Near Threatened. However, field staff found $>100$ active nest cavities of this species in the southern part of the Western Forest complex (THP, 2009), and more in other complexes. With a large number of available nest cavities and its high capacity to adapt to disturbed areas with regard to nest sites (Poonswad, 1998), we recommend that the present national status of Least Concern is retained.

Our study indicates that conservation efforts should be directed not only to protection of existing large areas of 
habitat in protected areas, as guided by DNP policy (Trisurat et al., 2010), but also to forest patches or degraded forests within ranging distance of large patches (Raman \& Mudappa, 2003; Sitompul et al., 2004). This is because large areas of hornbill habitat were predicted to occur outside protected areas. O’Brien et al. (1998) reported that small forest fragments may offer a safe haven for resting or roosting hornbills during dispersal and inter-forest movement, particularly when figs are in fruit. Kalyakool (2010) also found that hornbill fledglings in Hala Bala complex moved within disturbed forest and a few occurrences were detected outside protected areas. In addition, improving degraded habitats adjacent to protected area complexes and increasing connectivity of suitable habitats outside the current distributions, to facilitate species movement, are promising approaches for maintaining the population viability of hornbills (Trisurat et al., 2010).

Based on the results of this research we plan to do further modelling of changes in land cover, and consequent habitat loss and fragmentation, to support the conservation of species of hornbill categorized as Critically Endangered and Endangered. Our modelling and assessment approach could be applied to hornbill species in neighbouring countries, where data on species occurrences are also limited.

\section{Acknowledgements}

We thank National Center for Genetic Engineering and Biotechnology for funding this research project, the Royal Forest Department and Department of National Park, Wildlife and Plant Conservation for providing permission to conduct this research, David Reed for his valuable comments during the preparation of this article, and two anonymous reviewers for their constructive comments.

\section{References}

Anderson, R.P., Laverde, M. \& Peterson, A.T. (2002)

Geographical distributions of spiny pocket mice in South America: insights from predictive models. Global Ecology and Biogeography, $11,131-141$.

BirdLife International (2009) The BirdLife Checklist of the Birds of the World, with Conservation Status and Taxonomic Sources: Version 1. BirdLife International, Cambridge, UK.

DNP (Department of National Park, Wildlife and Plant Conservation) (2007) Statistic Data of National Park, Wildlife and Plant Conservation 2007. Ministry of Natural Resources and Environment, Bangkok, Thailand.

Fraterrigo, J.M., Pearson, S.M. \& Turner, M.G. (2009) Joint effects of habitat configuration and temporal stochasticity on population dynamics. Landscape Ecology, 7, 863-877.

Graham, C.H., Elith, J., Hijmans, R.J., Guisan, A., Peterson, A.T. \& Loiselle, B.A. (2008) The influence of spatial errors in species occurrence data used in distribution models. Journal of Applied Ecology, 45, 239-247.
Hosmer, D.W. \& Lemeshow, S. (2000) Applied Logistic Regression, and edition. Wiley, New York, USA.

IUCN (2001) 2001 Categories and Criteria (version 3.1). IUCN, Gland, Switzerland.

KALY KOOL, W. (2010) Use of radio-telemetry to determine habitat use of food resource of hornbill (Buceros bicornis) in non-breeding season in different forest types. MSc thesis. Mahidol University, Bangkok, Thailand.

KEMP, A.C. (2001) Family Bucerotidae (Hornbills). In Handbook of the Birds of the World (eds J. del Hoyo, A. Elliott \& J. Sargatal), Vol. 3, pp. 436-523. Lynx Edicions, Barcelona, Spain.

Kinnaird, M.F. \& O'Brien, T.M. (2007) The Ecology and Conservation of Asian Hornbills: Farmers of the Forest. The University of Chicago Press, Chicago, USA.

Kitamura, S., Yumoto, T, Poonswad, P., Chuallua, P. \& Plongmai, K. (2004) Characteristics of hornbill-dispersed fruits in a tropical seasonal forest in Thailand. Bird Conservation International, 14, 81-88.

LANDE, R. (1993) Risks of population extinction from demographic and environmental stochasticity and random catastrophes. American Naturalist, 142, 911-927.

Lehouck, V., Spanhove, T., Vangestel, C., Cordeiro, N.J. \& LENS, L. (2009) Does landscape structure affect resource tracking by avian frugivores in a fragmented Afrotropical forest? Ecography, 32, 789-799.

Lekagul, B. \& Cronin, E.W. (1974) Bird Guide to Thailand. Kurusapha Lardprao Press, Bangkok, Thailand.

Liu, C., Berry, P.M., Dawson, T.P. \& Pearson, R.G. (2005) Selecting thresholds of occurrence in the prediction of species distributions. Ecography, 28, 385-393.

O’Brien, T.M., Kinnaird, M.F., Jepson, P. \& Setiawan, I. (1998) Effect of forest size and structure on the distribution of Sumba hornbills Aceros everetti. In The Asian Hornbills: Ecology and Conservation (ed. P. Poonswad), pp. 209-218. National Center for Genetic Engineering and Biotechnology, Bangkok, Thailand.

Olson, D.M., Dinerstein, E., Wikramanayake, E.D., Burgess, N.D., Powell, G.V.N., Underwood, E.C. et al. (2001) Terrestrial ecoregions of the world: a new map of the life on earth. BioScience, 51, 933-938.

OneP (Office of Natural Resources and Environmental Policy and Planning) (2007) Thailand Red Data: Vertebrates. Ministry of Natural Resources and Environment, Bangkok, Thailand.

Pattanavibool, A., Dearden, P. \& Kutintara, U. (2004) Habitat fragmentation in north Thailand: a case study. Bird Conservation International, $14, \mathrm{~S}_{13}-\mathrm{S}_{22}$.

Peterson, A.T., Papes, M. \& Eaton, M. (2007) Transferability and model evaluation in ecological niche modeling: a comparison of GARP and Maxent. Ecography, 30, 550-560.

Phillips, S.J., Anderson, R.P. \& Schapire, R.E. (2006) Maximum entropy modeling of species geographical distributions. Ecological Modelling, 190, 231-259.

Poonswad, P. (1998) Current status and distribution of hornbills and their habitats in Thailand. In The Asian Hornbills: Ecology and Conservation (ed. P. Poonswad), pp. 436-475. National Center for Genetic Engineering and Biotechnology, Bangkok, Thailand.

Poonswad, P., Sukkasem, C., Phataramata, S., Hayeemuida, S., Plongmai, K., Chuallua, P. et al. (2005) Comparison of cavity modification and community involvement as strategies for hornbill conservation in Thailand. Biological Conservation, 122, 385-393.

RAMAN, T.R.S. \& MudAPPA, D. (2003) Correlates of hornbill distribution and abundance in rainforest fragments in the southern Western Ghats, India. Bird Conservation International, $13,199-212$. 
ReEd, D.H. (2010) Albatrosses, eagles, and newts, Oh My!: Exceptions to the prevailing paradigm concerning genetic diversity and population viability? Animal Conservation, 13, 448-457.

Sethi, P. \& Howe, H.F. (2009) Recruitment of hornbill-dispersed trees in hunted and logged forests of the Indian Eastern Himalaya. Conservation Biology, 23, 710-718.

Sitompul, A.F., Kinnaird, M.F. \& O’Brien, T.M. (2004) Size matters: the effects of forest fragmentation and resources available on the endemic Sumba hornbill Aceros everetti. Bird Conservation International, 14, S23-S37.

Theobald, D.M. (2005) GIS Concepts and ArcGIS Methods. Conservation Planning Technologies, Fort Collins, USA.

ThP (Thailand Hornill Project, Mahidol University) (2009) The Characteristics of Genetic of Hornbills in Fragmented Forest Landscape and Their Population and Habitat Status in Thailand. Unpublished Final Report submitted to the National Center for Genetic Engineering and Biotechnology, Bangkok, Thailand. [in Thai]

Tognelli, M.F., Roig-Junent, S.A., Marvald, A.E., Flores, G.E. \& Lово, J.M. (2009) An evaluation of methods for modeling distribution of Patagonian insects. Revista Chilena de Historia Natural, 82, 347-360.

Trisurat, Y., Pattanavibool, A., Gale, A.G. \& Reed, D. (2010) Improving the viability of large mammal populations using landscape indices for conservation planning. Wildlife Research, 36, 401-412.

Trisurat, Y. \& Toxopeus, A.G. (2011) Species distribution modeling. In Land Use, Climate Change and Biodiversity Modeling: Perspectives and Applications (eds Y. Trisurat, R.P. Shrestha \& R. Alkemade), pp. 171-197. IGI Global, Hershey, USA.

Wisz, M.S., Hijmans, R.J., Li, J., Peterson, A.T., Graham, C.H. \& GUISAN, A. (2008) Effects of sample size on the performance of species distribution models. Diversity and Distributions, 14, 763-773.

\section{Biographical sketches}

YONGYUT TRISURAT has been active in research on protected areas, biodiversity conservation, landscape ecology and species modelling for over 15 years. Vijak Chimchome, Anak Pattanavibool, Siriporn Thongaree, Budsabong Kanchanasakha, Saksit Simcharoen, Kriangsak Sribuarod and Narong Mahannop are interested in wildlife ecology and management, particularly mammals and birds. Sitthichai Jinamoy's research interest is in GIS modelling of animal distributions. Pila I PoOnSWAD has conducted research on hornbills in South-east Asia for more than 30 years. 